\title{
Why Choose Electrical Subjects? Profiling and Analyzing Motivations of Kuwaiti Pre-Service Teachers
}

\author{
Ebrahim Alanezi ${ }^{1}$ \\ ${ }^{1}$ College of Basic Education, PAAET, Kuwait \\ Correspondence: Ebrahim Alanezi, College of Basic Education, PAAET, Kuwait.
}

Received: June 21, 2021

Accepted: August 10, $2021 \quad$ Online Published: January 17, 2022

doi:10.5539/ies.v15n1p32

URL: https://doi.org/10.5539/ies.v15n1p32

\begin{abstract}
The aim of this study was to determine factors that influence Kuwaiti pre-service teachers' choice of Practical Electrical Subjects by profiling and analysing their motivations. Unlike previous studies that focused on the traditional conceptualisations of intrinsic, altruistic, and extrinsic motivations, this study uses the interpretive lens of Expectancy Value Theory which forms the foundation for the Factors Influencing Teacher Choice model to analyse and describe factors that influence the pre-service teachers' career choice decisions. One hundred fifty-six pre-service teachers enrolled in a teacher education programme completed the Factors Influencing Teacher Choice survey on which they rated 25 motivational factors. T-tests and One-way ANOVA were used to examine differences based on gender and year of study. Self-efficacy beliefs, social utility value, time for family, job security and prior teaching and learning experiences were important career choice determinants. Fall back career was the least important motivational factor. Gender was found to significantly influence their career choice while year of study did not significantly influence their decision. In general, female pre-service teachers appeared to be more motivated to choose teaching electricity as a practical subject than males. The pre-service teachers' year of the study showed significant variations only regarding social utility values and fallback career. The results of this study would contribute to existing literature on factors influencing pre-service teachers to choose a teaching career that involves vocational or practical subjects' teachers. Some theoretical and practical implications are drawn for pre-service teacher education.
\end{abstract}

Keywords: motivating factors, career choice, pre-service teachers, electricity, practical subject, fit-choice model, expectancy value theory

\section{Introduction}

\subsection{Background}

Teachers are considered responsible for promoting the social and emotional development of learners (Schonert-Reichl, 2017). They are keys for improving the overall quality of teaching (Fray \& Gore, 2018). While academic proficiency, TPACK and skills are important factors contributing to teacher effectiveness, academics claim that quality education cannot be achieved without teachers who are motivated (Han \& Yin, 2016; Ng, 2015). This is because pre-service teacher motivation has an impact on the quality of teaching. Also, Shin et al., (2017), proved that in their study career motivation has an important role as starting point in the student future and their academic track choice.

There is a new and growing research interest in teachers' motivation to teach due to reports of declining enrolments in teacher preparation programmes across the globe (Moss, 2020; Martin \& Mulvihill, 2016). Yet students are entering teacher training colleges as they are influenced by good remuneration and other workplace perks and benefits as well as perceptions of the prestige and social standing associated with the teaching profession (Martin \& Mulvihill, 2016). Such reasons are expected to raise public concerns about the quality of the teacher workforce (Floden, Stephens, \& Schere, 2020). In Kuwait, a reform-oriented Ministry of Education has been taking effective methods for addressing the reorientation of teacher education in order to alleviate public concerns about poor quality of teachers and poor Programme for International Student Assessment (PISA) results (OECD, 2019; Oxford Business Group, 2017). However, questions remain as to whether pre-service teachers are choosing to pursue a degree in teaching as a fallback career or whether they are opting to enter the profession out of a sense of duty or pressure from others, or because they are interested in teaching for altruistic reasons (Moss, 2020). 


\subsection{Problem Statement}

Although there is a wealth of research on teacher motivation in the field of general education (Low et al., 2017; Heinz, 2015; Moreau, 2014), there seems to be few studies that have investigated the motivations to become a teacher of practical subjects such as electricity. Practical subjects taught in intermediate schools in Kuwait are considered to be vital in the development of a student and to provide career pathways, for instance to develop creative and problem-solving skills (Alanezi, 2018). Less is known about how teachers' values for teaching and their motivation to entering and persisting in the field differ at various stages of their professional training and career. Therefore, investigating the career motivation of future teachers is important.

Unlike many countries, Kuwait has a shortage of qualified teachers, and this is exacerbated by COVID-19 which prompted the Ministry of Education to stop hiring staff from overseas (Gulf News, Dec, 2020). Most Kuwaitis, especially women, prefer teaching to other professions (Bianco, 2017). Therefore, the study of what attracts students to become teachers is highly significant. Moreover, there are a few studies which have addressed pre-service teachers' motivation in Kuwait. The goal of this study is to profile and analyse pre-service teachers' career choice motivations to teach practical electrical subjects. The purpose of the present study was to examine the motivational factors based on demographic characteristics such as gender and year of study. Research analysing pre-service teachers' career choice motivation and their preference for specific subject areas or domains could inform policy initiatives focusing on recruitment and retainment of future teachers (Dietrich \& Lazarides, 2019; Lauermann et al., 2017).

\subsection{Research Questions}

This study addresses the following research questions:

RQ1: What are the career motivations of pre-service teachers for choosing to teach electricity as a practical subject?

RQ2: Are there any gender differences in the career motivations of pre-service teachers' for choosing to teach electricity as a practical subject?

RQ3: Are there any differences in the career motivations of pre-service teachers belonging to ' for choosing to teach electricity as a practical subject based on their year of study?

\section{Literature Review}

A critical review of existing literature was undertaken on topics that were pertinent and related to career motivations of pre-service teachers. Care was taken to include recent studies wherever possible. Almost all the articles reviewed are specific to the field of career motivations of pre-service teachers. The descriptors used for searching and locating the resources were 'motivating factors', 'career choice', 'pre-service teachers', 'electricity', 'practical/vocational subject', 'Factors Influencing Teaching Choice Model' or 'FIT-Choice Model' and 'Expectancy Value Theory'.

\subsection{Motivation and Career Choice Selection}

Motivation is a driving factor or the reason why individuals are willing to pursue an activity (Han \& Yin, 2016). Job satisfaction, self-determination, self-efficacy, and self-enhancement values or personal achievement are vital elements of teacher motivation (Barni, Danioni, \& Benevene, 2019; McLean et al., 2019; Chesnut \& Burley, 2015). Individuals develop interest in teaching because they believe they are competent and that the profession will have a positive effect on their personal development, social status and esteem (Serra et al., 2019; Torsney, Lombardi, \& Ponnock, 2019; Wyatt-Smith et al., 2017). In other words, social context plays a key role in the development of interest toward the profession (Serra et al., 2019; Ponnock, Torsney, \& Lombardi, 2018). This suggests that interest is a powerful motivational process which is triggered or stimulated as a consequence of being in a particular environment or situation (Torsney et al., 2019; Harackiewicz, Smith, \& Priniski, 2016).

It is argued that individuals choose teaching as a career because of intrinsic values, such as interest in or passion for teaching, for creating a desirable (professional) life, and to make a difference in society (Bergmark et al., 2018; Wyatt-Smith et al. 2017). There are also altruistic motivates because individuals consider teaching to be of social value and are interested in promoting personal and social development (Htang, 2019). Consequently, career choice selection is impacted by interest, competence, career growth and altruistic motives (Torsney et al., 2019; Low et al., 2017; Tomšik, 2016). Others claim that career motivation in education is mostly characterized by extrinsic motivational factors or rewards, for example salary, status, and working conditions (Shin et al., 2017; Howard-Jones \& Jay, 2016; Murayama \& Kitagami, 2014). Murayama et al. (2016) argue that extrinsic rewards can at times undermine or reduce intrinsic motivation. Thus, most studies that focused on teacher career 
choice motivation have adopted the traditional conceptualisations of intrinsic, altruistic and extrinsic motivations (Low et al., 2017).

In the context of Kuwait, it is not known if teachers are choosing practical subjects influenced by intrinsic, extrinsic or altruistic or any other factors. This study argues that individuals in Kuwait are motivated by their interest in gaining something by choosing to teach electricity based not only on preconceived notions and "culturally blind" attitudes but also under the "fallacy of homogeneity" (Nie et al., 2013, p. 74).

\subsection{Factor Influencing Pre-Service Teachers to Pursue Teaching as a Career}

There are several factors that influence pre-service teachers' motivation to teach electricity as a practical subject. Teachers' interest in a subject or the need to contribute to society emanate from their intrinsic values to choose to teach a subject for example self-respect, responsibility, and a sense of accomplishment (Watt et al., 2017; Wyatt-Smith et al., 2017; Watt \& Richardson, 2007). Teachers' motivation is also influenced by a number of contextual factors for instance the desire to earn greater remuneration, the desire for job security or financial stability, the desire to build career reputation, the influence of family members, friends or relatives, and inability to get into other educational fields (Carrico, Matusovich, \& Paretti, 2019; Wyatt-Smith et al., 2017; Topkaya \& Uztosun, 2012; Watt \& Richardson, 2007). However, these choices may be made without much knowledge or consideration of what constitutes a career in teaching electricity as a practical subject.

One such factor is socialisation or the process of learning to behave in a way that is acceptable to society. This implies that as agents of social change, teachers should use their competence in teaching a specific subject to contribute to their local communities (Bourn, 2016). This is referred to as professional socialization or the way in which pre-service (and in-service) teachers get exposed to or learn and unconsciously assimilate the socially constructed norms, actions, and knowledge of teaching as a profession (Maloney, 2013). It is a lifelong process and occurs through interaction with experienced members of the society and media either consciously or otherwise (Sadeghi, Yazdani, \& Afshar, 2019; Salisu et al., 2019). Socialisation plays an influential role in shaping teachers' motivational processes for example prior teaching and learning experiences (Moss et al., 2020; Low et al., 2017). While these prior teaching experiences can influence a teacher's interest in teaching, other important socialisation factors include family members and/or schoolteachers (Low et al., 2017). Other motivational influences that contribute to a teacher's decision to pursue a teaching career emerge from interactions with parents, siblings, extended family or role models, interest in a subject, and other social influences (Watt, Richardson, \& Wilkins, 2014). In other words, these individuals may choose teaching because of their interactions with someone in their direct social network (Mariscal \& Delgado, 2016).

In addition to being influenced by socialisation factors, their goals and interests, teachers' motivations are affected by specific beliefs about their capabilities (Nesje, Brandmo, \& Berger, 2018; Topkaya \& Uztosun, 2012). A teacher's self-efficacy beliefs pertain to the judgment of their abilities to organize and effectively accomplish a task (Bandura, 1997). It determines how teachers feel, think, motivate themselves and behave (Kim, 2015). Teaching self-efficacy might also be related to career choice since it can be considered as a motivational process (Kim, 2015; Bilim, 2014).

Garra-Alloush, Chaleila, and Watted (2021) examined motivational factors influencing teaching as a career choice among female Israeli-Arab students and found that their future career choice was mainly driven by intrinsic values and a strong interest in teaching English as a foreign language. Extrinsic factors, such as the belief that the profession can help balance motherhood and professional life perfectly and that it can ensure a comparatively comfortable lifestyle were significant findings.

Stellmacher et al. (2020) investigated the career choice motivation of pre-service vocational education and training (VET) teachers as compared to the motivation of future comprehensive schoolteachers in Germany. The vocational education and training (VET) teachers rated their interest in teaching especially subject-specific and educational interest, social influences, and utility as significantly less relevant in terms of their career choice motivation. Females considered work-life balance to play a more important role for choosing teaching profession. In contrast, male pre-service teachers in South Korea believed that they chose teaching as a profession because they were influenced by others and perceptions of task return (Lee, Kang, \& Park, 2019). This suggests that context also influences teacher motivation and corroborates results of other studies (for e.g., Carrico et al., 2019; Matusovich et al., 2017).

Brandmo and Nesje (2017) investigated factors motivating students to become secondary school teachers in Norway and also examined how altruistic motivation relates to gender, intrinsic value of teaching, ability perceptions, and family background. Results of the survey administered to 635 students indicate that the pre-service teachers' motivation to teach was not very different from that of student-teachers from other 
countries. Motivational factors with higher ratings included self-efficacy beliefs, intrinsic value of teaching, social utility values and subject interest. The results also revealed that female students rated altruistic values higher than the male students. The results of this Norwegian study were confirmed by Fray and Gore (2018) who claimed that most teachers are motivated to choose the profession for primarily altruistic reasons.

Htang (2019) explored the teaching motivations of 306 first-year pre-service teachers. Quantitative results indicated that females were more extrinsically motivated to be a teacher than males. The study found that there were significant differences in pre-service teachers' motivation in terms of their satisfaction with the choice based on gender. Their socio-economic background and cultural and religious beliefs were other factors that motivated them to choose a career in teaching. These results corroborate findings of previous studies that have shown that socio-cultural factors such as religion can influence pre-service teacher' motivations and aspirations for entering teacher education (Watt et al., 2017; Suryani, 2017).

A multi-country investigation of teaching motivations (Han, Borgonovi, \& Guerriero, 2018) found that societal values and appraisals about the importance of a teaching job and respect were positively associated with career expectations, while working hours was negatively associated with beliefs related to their career. Results also revealed that salary was an important factor. However, salary is a contextual factor. For example, while male pre-service teachers in South Korea do not perceive salary as an incentive to choosing teaching career (Htang, 2019), female teachers in Myanmar were content with a teaching job although the remuneration was low (Higgins et al., 2016). Consequently, low salaries have resulted in the feminisation of teaching profession in some parts of the world (Higgins et al., 2016, p. 126).

Fokkens-Bruinsma and Canrinus (2012) used the FIT-Choice (Factors Influencing Teaching Choice) scale in a Dutch educational context and found that the main motivational factors for becoming a teacher were their self-efficacy beliefs, emotional attachment to the profession and previous teaching and learning experiences. Other factors included making a social contribution by working with children and adolescents, the need to spend more time with family, as well as perceived beliefs that teaching is a profession that requires specialized knowledge and commitment (task demand), and task return or the perception that teaching offers a high social status, high self-esteem, and a good remuneration.

Another study also found that pre-service teachers' motivational factors included making a social contribution by shaping the future of children and advancing education equity (Bilim, 2014). In other words, the teachers want to shape the future of children and adolescents (Nesje et al., 2018). Although prior teaching and learning experiences and job security have a big impact on motivation, choosing teaching as a "fallback" career has been reported as a low-ranking factor in many studies (Abotsi et al., 2020; Glutsch \& König, 2019; Nesje et al., 2018; Bilim, 2014). This finding was recently validated by a study in which most pre-service teachers believed that teaching is a "last-resort choice" or a "default career" (Garra-Alloush et al., 2021, p. 55).

The background characteristics of pre-service teachers are regarded as a helpful tool for predicting motivation to teach (Watt \& Richardson 2007). Consequently, the background characteristics of student teachers and their motivation to enrol on a teacher training program have received considerable attention from contemporary researchers (Watt, Richardson \& Smith, 2017; Qin et al., 2015). Studies have found that year of study or academic levels can affect pre-service teacher motivation (Ponnock et al., 2018; Wyatt-Smith et al., 2017).

In a recent study, Abonyi, Awhireng, and Luguterah (2020) investigated pre-service teachers' motivation for choosing teaching as a career in Ghana. The study found that the desire to shape the future of young people, prior teaching and learning experiences, and self-efficacy beliefs or teaching skills influenced their career choice decisions. This was very true of female pre-service teachers who also considered job security, time for family, and the desire to contribute to society as important motivational factors compared to males. These results (of Aboyi et al., 2020) confirm the claim that gender affects how individuals set personal goals based on their expected career pathways (Serra et al., 2019). However, researchers claim that females are less likely to remain in the high motivation profile as compared to males (Dietrich \& Lazarides, 2019). Although there is a considerable number of studies on the association between gender and motivational beliefs (Htang, 2019; Brandmo \& Nesje, 2017), there is a lack of research exploring pre-service teachers' motivational beliefs in specific domains (Dietrich \& Lazarides, 2019). Moreover, gender is an important factor as more women enter the teacher profession compared to men in many countries including Kuwait (Serra et al., 2019; Bianco, 2017).

\subsection{Factors Influencing Teaching Choice Framework}

The tripartite framework (Kyriacou \& Coulthard, 2000) which has been cited extensively as a model on teaching motivations focuses on intrinsic, altruistic and extrinsic motivations. Intrinsic motives are internal and include an individual's satisfaction (for example interest) with teaching a subject, while people with altruistic motives 
consider teaching as socially meaningful and contributing to the society. Extrinsic motivation is a person's behaviour that is driven by external rewards or other benefits related to teaching (e.g. salary, social status, respect, working conditions and holidays, etc.). However, the tripartite framework is very broad and does not capture the complex nature of teachers' motivations for choosing a career or teaching a specific subject.

The FIT-Choice framework, founded on expectancy-value theory, provides a comprehensive and coherent model to guide systematic investigation into the question of why people choose a teaching career (Watt $\&$ Richardson, 2007). The expectancy-value theory has been widely used to explain how expectancies for accomplishment and values directly and indirectly influence career choice, performance, exertion, and purpose (Wigfield \& Eccles, 2000). Based on the expectancy-value theory, the FIT-Choice framework includes several key elements: self-perceptions or self-efficacy beliefs, intrinsic career values (a genuine, intrinsic interest in teaching), personal utility value, or the view that teaching is convenient to their desired lifestyle, social utility value, or the extent to which one values making a positive contribution to society through working with children (an altruistic motivation), fallback career, social influences (extrinsic motivation), prior teaching and learning experiences (extrinsic motivation), as well as task demand perceptions and task return (McLean, Taylor \& Jimenez, 2019; Low et al., 2017). Although the FIT-Choice framework may appear similar to the tripartite framework it captures teaching motivations in a more profound manner (Low et al., 2017). Moreover, the FIT-Choice expectancy-value motivational model is particularly useful in investigating motivating factors for choosing a teaching career (Watt \& Richardson, 2007). The FIT-Choice framework was used in this study as it is a reliable measure that allows comparisons across samples and setting to study the complex interaction of factors embedded within communities and cultural expectations (Watt et al., 2017).

\section{Research Methodology}

This quantitative study uses a survey method to gather information of pre-service teachers' motivational beliefs for choosing and teaching electricity as a practical subject. The dependent variables are intrinsic career values, self-efficacy beliefs, job security, time for the family, prior teaching and learning experiences, social utility values, choice as a result of fallback, and task demand/return. The independent variables are gender and year of study.

\subsection{Sample}

The study took place at the College of Basic Education, Kuwait during the 2020-21 academic year. The sample consisted of 156 pre-service teachers who took part in the study voluntarily. They were selected from a total of 323 student teachers who were enrolled in instructional courses associated with electricity. The participating pre-service teachers gave written informed consent. The demographic characteristics of the participants are tabulated below.

Table 1. Demographic characteristics

\begin{tabular}{ccc}
\hline \multicolumn{2}{c}{ Characteristics } & Frequency \\
\hline \multirow{2}{*}{ Gender } & Male & 36 \\
& Female & 120 \\
Year & 1 & 25 \\
& 2 & 9 (Male 1, Female 8) \\
Age groups & 3 & 122 (Male 35, Female 87) \\
(in years) & $22-25$ & 116 \\
& 26 and over & 6 \\
\hline
\end{tabular}

As seen in the table, most participants were female $(\mathrm{N}=120)$ as more Kuwaiti women choose teaching as a profession. Although the participants were drawn from various classes or year of study, most of them were enrolled in year 3 of their teacher training programme. They also belonged to different age groups.

\subsection{Research Instrument}

Pre-service teachers' motivations for choosing to teach electrical subjects as a career were investigated using the FIT- Choice scale (Watt \& Richardson, 2007). One of the reasons for the choice of the FIT-Choice scale was because it was developed with the objective of guiding a methodological inquiry into the question of why individuals choose a teaching profession (Watt \& Richardson, 2007). Moreover, the scale is an empirically 
validated theoretical model (Watt \& Richardson, 2012). The survey asks respondents to share their motivations for choosing to teach practical subject and their beliefs about teaching electricity. All items in the questionnaire were marked based on a five-point Likert style level of response ranging from strongly agree to strongly disagree (strongly agree-5, Agree-4, neither agree nor disagree-3, disagree-2, strongly disagree-1).

\subsubsection{Validity and Reliability}

This scale was initially developed and validated in various contexts, and applied across international samples from Australia, Germany, the Netherlands, Norway, and the United States (Nesje et al., 2018; Watt et al., 2012). Studies support the cross-cultural validity of the FIT-Choice framework (for e.g., McLean et al., 2019; den Brok et al., 2013). These studies accentuate that motivation plays a role in choosing a teaching career anywhere in the world.

To check reliability of the instruments within the context of Kuwait, a pilot test was conducted with a small group of participants similar to those who took part in this study. Following the pilot test, a few questions were re-ordered. Some of the variables were excluded, for example, job transferability and items associated with this construct that read "teaching will be a useful job for me when travelling" or "A teaching job will allow me to choose where I wish to live" since they are not applicable for Kuwaiti pre-service teachers. The revised scale was given its final form and includes 25 items.

Construct and content validity were assessed to ensure that the constructs and items were developed based on relevant existing knowledge. A panel of experts evaluated the penultimate and final versions of the research instrument for its relevance, clarity, meaningfulness, completeness and ensured that the items were representative of all aspects of the construct (Halek et al., 2017). The adapted version of the FIT-Choice survey was assessed for internal consistency. Reliability was demonstrated with Cronbach's alpha coefficient of 0.760 for the entire scale. The FIT-Choice constructs and their reliability scores, as measured by Cronbach's $\alpha$, are presented in Table 2.

Table 2. Reliability of FIT-Choice constructs

\begin{tabular}{lc}
\hline Constructs & $\alpha$ \\
\hline Intrinsic values & 0.882 \\
Self-efficacy beliefs & 0.678 \\
Job security & 0.810 \\
Time for the family & 0.698 \\
Previous teaching and learning experiences & 0.814 \\
Social utility values & 0.809 \\
Fallback career & 0.746 \\
Task demand/Return & 0.648 \\
\hline
\end{tabular}

\section{Results}

\subsection{Motivational Factors That Influence Pre-Service Teachers to Choose a Career in Teaching Electricity as a Practical Subject}

The first research question asked what motivational factors influenced pre-service teachers to choose a career in teaching electricity as a practical subject. To answer this question, descriptive statistics (means and standard deviations) were used. 
Table 3. Descriptive statistics: Motivational factors that influence pre-service teachers

\begin{tabular}{|c|c|c|c|c|c|c|c|c|}
\hline \multirow{2}{*}{\multicolumn{2}{|c|}{ Constructs }} & \multirow{2}{*}{ Variables } & \multicolumn{3}{|c|}{ Male } & \multicolumn{3}{|c|}{ Female } \\
\hline & & & M & SD & CMV & M & SD & $\mathrm{CMV}$ \\
\hline \multirow{3}{*}{ IV } & 1 & I am interested in teaching Electricity as a subject & 3.44 & 0.50 & \multirow{3}{*}{3.74} & 2.92 & 0.57 & \multirow{3}{*}{3.04} \\
\hline & 2 & I have always wanted to be a teacher & 3.72 & 0.45 & & 3.09 & 0.73 & \\
\hline & 3 & I like teaching practical subjects & 4.06 & 0.71 & & 3.13 & 0.79 & \\
\hline \multirow{3}{*}{ SB } & 4 & I have the qualities of a good teacher & 3.79 & 0.77 & \multirow{3}{*}{3.87} & 4.01 & 0.59 & \multirow{3}{*}{3.94} \\
\hline & 5 & I have good teaching skills especially in teaching the subject & 3.81 & 0.39 & & 3.83 & 0.38 & \\
\hline & 6 & Teaching is a career suited to my abilities & 4.00 & 0.61 & & 4.00 & 0.59 & \\
\hline \multirow{3}{*}{ JS } & 7 & Teaching Electricity offers a steady career path & 3.76 & 0.77 & \multirow{3}{*}{3.73} & 3.97 & 0.66 & \multirow{3}{*}{3.94} \\
\hline & 8 & Teaching Electricity can provide a reliable income & 3.62 & 0.65 & & 3.83 & 0.38 & \\
\hline & 9 & Teaching Electricity will be a secure job & 3.81 & 0.75 & & 4.02 & 0.61 & \\
\hline \multirow{2}{*}{$\mathrm{TF}$} & 10 & Teaching hours fits with responsibilities of having a family & 4.20 & 0.84 & \multirow{2}{*}{4.09} & 4.54 & 0.52 & \multirow{2}{*}{4.42} \\
\hline & 11 & School holidays will fit in with family commitments & 3.98 & 0.95 & & 4.30 & 0.72 & \\
\hline \multirow{3}{*}{ PTLE } & 12 & Inspirational teachers taught me Electricity as a subject & 3.14 & 0.82 & \multirow{3}{*}{3.29} & 3.15 & 0.83 & \multirow{3}{*}{3.30} \\
\hline & 13 & I have had good teachers as role-models & 3.38 & 0.55 & & 3.39 & 0.54 & \\
\hline & 14 & I have positive learning experiences & 3.35 & 0.92 & & 3.37 & 0.92 & \\
\hline \multirow{4}{*}{ SUV } & 15 & My friends think I should teach Electricity as a subject & 4.27 & 0.93 & \multirow{4}{*}{3.85} & 4.59 & 0.74 & \multirow{4}{*}{4.05} \\
\hline & 16 & Family members think I should teach Electricity as a subject & 3.69 & 0.56 & & 3.87 & 0.34 & \\
\hline & 17 & People think that I should teach Electricity as a subject & 3.87 & 0.70 & & 3.98 & 0.49 & \\
\hline & 18 & I want to contribute to society by teaching this subject & 3.56 & 0.65 & & 3.76 & 0.43 & \\
\hline \multirow{3}{*}{$\mathrm{FC}$} & 19 & Initially, I was unsure of what career I wanted & 3.78 & 0.42 & \multirow{3}{*}{3.91} & 2.28 & 0.74 & \multirow{3}{*}{2.44} \\
\hline & 20 & I may not be accepted into my first-choice career & 3.64 & 0.49 & & 2.32 & 0.55 & \\
\hline & 21 & I chose teaching Electricity as a last-resort career & 4.31 & 0.71 & & 2.72 & 0.52 & \\
\hline \multirow{4}{*}{ TDR } & 22 & Requires specialized knowledge but has high demand & 3.12 & 0.63 & \multirow{4}{*}{3.61} & 3.09 & 0.62 & \multirow{4}{*}{3.56} \\
\hline & 23 & It offers an expert career path & 3.54 & 0.75 & & 3.51 & 0.77 & \\
\hline & 24 & It will improve my social status & 3.72 & 0.72 & & 3.68 & 0.76 & \\
\hline & 25 & I can get high salary & 4.04 & 0.85 & & 3.96 & 0.89 & \\
\hline
\end{tabular}

Note. IM=Intrinsic values, $\mathrm{SB}=$ Self-efficacy beliefs, JS= Job security, TF=Time for family, PTLE=Previous teaching/ learning experiences, $\mathrm{SUV}=$ Social utility values, $\mathrm{FC}=$ Fallback career, TDR=Task demand/Return, $\mathrm{M}=$ Mean, $\mathrm{SD}=$ Standard Deviation, $\mathrm{CBV}=$ Construct Mean Average.

The results (Table 3) shows that the highest-rated motivational factors that influenced both male and female pre-service teachers for choosing a career in teaching electricity as a profession was time for family (Male $\mathrm{M}=4.09$; Female $\mathrm{M}=4.42$ ), their self-efficacy beliefs (Male $\mathrm{M}=3.87$; Female $\mathrm{M}=3.94$ ), job security (Male $\mathrm{M}=3.73$; Female $\mathrm{M}=3.94$ ), and social utility values (Male $\mathrm{M}=3.85$; Female $\mathrm{M}=4.05$ ). This was followed by other factors such as interest in teaching electricity as a profession (Male $\mathrm{M}=3.74$; Female $\mathrm{M}=3.04$ ), to have positive learning experiences (Male $\mathrm{M}=3.29$; Female $\mathrm{M}=3.30$ ) and that teaching as a career requires specialized knowledge but has high demand (Male $\mathrm{M}=3.61$; Female $\mathrm{M}=3.56$ ). However, with regard to their perceptions of teaching as a fallback career, male and female pre-service teachers had different opinions. Males indicated that they had previously wanted to pursue another career prior to entering teacher education and chose teaching electricity as a last-resort career $(\mathrm{M}=3.91)$. The descriptive statistics shows that male and females teachers had different views with regard to intrinsic values and choosing teaching as a fallback career. In order to understand these differences, t-tests and one-way ANOVA were computed.

\subsection{Pre-Service Teachers' Motivations Across Demographic Characteristics}

\subsubsection{Motivations Based on Gender}

The purpose of the second research question is to find out if there are any gender differences in the career motivations of pre-service teachers' for choosing to teach electricity as a practical subject. Independent t-tests were conducted to explore the effect of gender on pre-service teachers' motivation for choosing a career in teaching electricity as a practical subject.

The null hypothesis tested was:

$H_{0} 1$ : There is no statistically significant difference in pre-service teachers' motivation to teach electricity as a practical subject based on gender. 
Table 4. Gender differences in pre-service teachers' motivations

\begin{tabular}{|c|c|c|c|c|c|}
\hline Constructs & Gender & Mean & $\mathrm{t}$ & df & Sig.(2- tailed) \\
\hline \multirow{2}{*}{ Intrinsic values } & Male & 3.74 & \multirow{2}{*}{7.135} & \multirow{2}{*}{76} & \multirow{2}{*}{$0.000 *$} \\
\hline & Female & 3.04 & & & \\
\hline \multirow{2}{*}{ Self-efficacy beliefs } & Male & 3.61 & \multirow{2}{*}{-3.733} & \multirow{2}{*}{48} & \multirow{2}{*}{$0.000^{*}$} \\
\hline & Female & 3.94 & & & \\
\hline \multirow{2}{*}{ Job security } & Male & 3.03 & \multirow{2}{*}{-7.665} & \multirow{2}{*}{43} & \multirow{2}{*}{$0.000^{*}$} \\
\hline & Female & 3.94 & & & \\
\hline \multirow{2}{*}{ Time for the family } & Male & 2.99 & \multirow{2}{*}{-11.517} & \multirow{2}{*}{50} & \multirow{2}{*}{$0.000 *$} \\
\hline & Female & 4.42 & & & \\
\hline \multirow{2}{*}{ Previous teaching and learning experiences } & Male & 3.25 & \multirow{2}{*}{-0.402} & \multirow{2}{*}{56} & \multirow{2}{*}{$0.689^{* *}$} \\
\hline & Female & 3.30 & & & \\
\hline \multirow{2}{*}{ Social utility values } & Male & 3.18 & \multirow{2}{*}{-8.908} & \multirow{2}{*}{49} & \multirow{2}{*}{$0.000 *$} \\
\hline & Female & 4.04 & & & \\
\hline \multirow{2}{*}{ Fallback career } & Male & 3.91 & \multirow{2}{*}{16.347} & \multirow{2}{*}{66} & \multirow{2}{*}{$0.000 *$} \\
\hline & Female & 2.43 & & & \\
\hline \multirow{2}{*}{ Task demand/Return } & Male & 3.74 & \multirow{2}{*}{2.276} & \multirow{2}{*}{84} & \multirow{2}{*}{$0.025^{*}$} \\
\hline & Female & 3.56 & & & \\
\hline
\end{tabular}

$* \mathrm{p}<0.05 ; * \mathrm{p}>0.05$

The t-test results (Table 4) showed that there were significant differences between male and female pre-service teachers regarding their motivation for choosing their career in teaching $(p<0.05)$. This suggests that the null hypothesis is rejected, and the motivational beliefs of males are not significantly different from females. However, for previous teaching and learning experiences the significance was found at the .05 or .01 level, and the results for this construct showed that the genders were not that different in their responses

\subsubsection{Motivations Based on Year of Study}

The purpose of the third research question is to examine if there are any differences in the career motivations of pre-service teachers based on their year of year of study. It is evident from the descriptive statistics that there were some differences (Mean) in the pre-service teachers' motivations based on year of study.

Table 5. Group differences (Mean) in pre-service teachers' motivations based on year of study

\begin{tabular}{ccccccccc}
\hline Year & $\begin{array}{c}\text { Intrinsic } \\
\text { values }\end{array}$ & $\begin{array}{c}\text { Self-efficacy } \\
\text { beliefs }\end{array}$ & $\begin{array}{c}\text { Job } \\
\text { security }\end{array}$ & $\begin{array}{c}\text { Time for the } \\
\text { family }\end{array}$ & $\begin{array}{c}\text { Previous } \\
\text { teaching/ } \\
\text { learning } \\
\text { experiences }\end{array}$ & $\begin{array}{c}\text { Social utility } \\
\text { values }\end{array}$ & $\begin{array}{c}\text { Fallback } \\
\text { career }\end{array}$ & $\begin{array}{c}\text { Task } \\
\text { demand/ } \\
\text { Return }\end{array}$ \\
\hline $\begin{array}{c}\text { Year } \\
1\end{array}$ & 3.27 & 3.95 & 3.92 & 4.40 & 3.24 & 4.12 & 2.35 & 3.45 \\
$\begin{array}{c}\text { Year } \\
2\end{array}$ & 3.33 & 4.11 & 3.89 & 4.33 & 3.11 & 3.83 & 2.70 & 3.64 \\
$\begin{array}{c}\text { Year } \\
3\end{array}$ & 3.19 & 3.83 & 3.67 & 4.01 & 3.31 & 3.79 & 2.87 & 3.64 \\
\hline
\end{tabular}

Therefore, one-way ANOVA tests were conducted to determine whether pre-service teachers' motivations for choosing a career in teaching electricity as a practical subject differed significantly in terms of their year of study. The null hypothesis tested was:

$H_{0} 2$ : There is no statistically significant difference in pre-service teachers' motivation to teach electricity as a practical subject based on year of study. 
Table 6. ANOVA (One way): Group differences in pre-service teachers' motivations based on year of study

\begin{tabular}{|c|c|c|c|c|c|c|}
\hline Construct & Source of Variation & SS & $\mathrm{df}$ & MS & $\mathrm{F}$ & P-value \\
\hline \multirow{2}{*}{ Intrinsic values } & Between 3 Groups & 0.287 & 2 & 1.44 & 0.321 & $0.73 * *$ \\
\hline & Within 3 Groups & 68.455 & 153 & 0.44 & & \\
\hline \multirow{2}{*}{ Self-efficacy beliefs } & Between 3 Groups & 0.856 & 2 & 0.43 & 2.359 & $0.09^{* *}$ \\
\hline & Within 3 Groups & 27.761 & 153 & 0.18 & & \\
\hline \multirow{2}{*}{ Job security } & Between 3 Groups & 1.499 & 2 & 0.75 & 1.98 & $0.14 * *$ \\
\hline & Within 3 Groups & 57.943 & 153 & 0.38 & & \\
\hline \multirow{2}{*}{ Time for the family } & Between 3 Groups & 3.75 & 2 & 1.88 & 2.68 & $0.07 * *$ \\
\hline & Within 3 Groups & 106.99 & 153 & 0.7 & & \\
\hline \multirow{2}{*}{ Previous teaching and learning experiences } & Between 3 Groups & 0.42 & 2 & 0.21 & 0.46 & $0.63 * *$ \\
\hline & Within 3 Groups & 70.4 & 153 & 0.46 & & \\
\hline \multirow{2}{*}{ Social utility values } & Between 3 Groups & 2.22 & 2 & 1.11 & 3.41 & $0.04 *$ \\
\hline & Within 3 Groups & 49.85 & 153 & 0.33 & & \\
\hline \multirow{2}{*}{ Fallback career } & Between 3 Groups & 5.769 & 2 & 2.885 & 4.68 & $0.01^{*}$ \\
\hline & Within 3 Groups & 94.305 & 153 & 0.616 & & \\
\hline \multirow{2}{*}{ Task demand/Return } & Between 3 Groups & 0.74 & 2 & 0.37 & 1.38 & $0.25^{* *}$ \\
\hline & Within 3 Groups & 40.78 & 153 & 0.27 & & \\
\hline
\end{tabular}

There were no statistically significant differences $(p=>.05)$ between $1^{\text {st }}, 2^{\text {nd }}$ and $3^{\text {rd }}$ year pre-service teachers as determined by one-way ANOVA for six out of the eight constructs, namely intrinsic values $(F(0.321), p=0.73)$, self-efficacy beliefs $(F(2.359), p=0.09)$, job security $(F(1.98), p=0.14)$, time for the family $(F(2.68), p=0.07)$, previous teaching and learning experiences $(F(0.46), p=0.63)$, and task demand/return $(F(1.38), p=0.25)$. The p-values are greater than the significance level, and therefore there is not enough evidence to reject the null hypothesis (Ho2).

The p-value corresponding to the F-statistic of one-way ANOVA was lower than 0.05 for two constructs social utility values $(F(3.41), p=0.04)$ and fallback career $(F(4.68), p=0.01)$ suggesting there were significant differences $(p=>.05)$ between $1^{\text {st }}, 2^{\text {nd }}$ and $3^{\text {rd }}$ year pre-service teachers. However, these results do not specify which groups account for the significance. To find the differences between the groups, the Tukey test was performed on the data.

Table 7. Tukey HSD - Comparisons among Groups

\begin{tabular}{|c|c|c|c|}
\hline \multirow{2}{*}{\multicolumn{2}{|c|}{ Groups }} & \multirow[b]{2}{*}{ Mean difference } & \multirow[b]{2}{*}{$\mathrm{p}$-value } \\
\hline & & & \\
\hline Social utility value & Year 1 vs Year 3 & 3.6899 & $0.027^{*}$ \\
\hline Fallback career & Year 1 vs Year 3 & 4.308 & $0.008 * *$ \\
\hline
\end{tabular}

$* \mathrm{p}<0.05 ; * * \mathrm{p}<0.01$.

From the results, it is evident that a statistically significant difference exists between pre-service teachers belonging to year 1 and year $3(p<.05 ; p<.01)$. The test does not break down the significance at the item level, only for overall means by construct.

\section{Discussion}

This study has profiled pre-service teachers' motivations for choosing electricity as a practical subject for teaching through the lens of FIT-Choice model and the expectancy-value model. Framed in the expectancy value model, this study examined pre-service teachers' motivation for choosing to teach electricity as a practical subject.

\subsection{Career Motivations of Pre-Service Teachers to Teach Electricity as a Practical Subject}

The results of this study showed that self-efficacy beliefs, social utility value, and prior experience of teaching and learning are important determinants to the decision of becoming pre-service teachers. Descriptive statistics demonstrate that the pre-service teachers chose a career in teaching electricity as a profession because they could allocate more time for family, holidays and that it provided job security. The pre-service teachers' evaluations of their own ability to teach, or self-efficacy beliefs, are an important indicator of their ability and are crucial for 
deciding whether to pursue a teaching career. This aligns well with literature highlighting the positive effects of high self-efficacy (McLean et al., 2019; Chesnut \& Burley, 2015).

Results also suggest that preservice teachers made their career choice for contributing to the society. This finding is consistent with earlier studies (Abotsi et al., 2020; Brandmo \& Nesje, 2017; Bourn, 2016) that have claimed that social utility values is an important motive that influences pre-service teachers to pick teaching as a career choice. Literature also suggests that socialisation influences or prior teaching and learning experiences is one of the most important motivators for teachers when making their career choice (Lee et al., 2019; Hennessy \& Lynch, 2017; Low et al., 2017; Fokkens-Bruinsma \& Canrinus, 2012; Watt et al., 2012). These perceptions capture the expectancy and values component of the expectancy value model.

Other motivational factors are intrinsic values and task demand and task return. The pre-services teachers believed that the intrinsic career values, for example subject-specific interest, motivated them as it offered professional advancement opportunities. This finding aligns with the literature on the significance of interest as a motivational factor (Torsney, Lombardi, \& Ponnock, 2019). This is consistent with previous research that interest in teaching (Serra et al., 2019; Bergmark et al., 2018) is a powerful motivational factor. Moreover, the pre-service teachers considered teaching as a career that is high in demand with better job prospects although it requires requires specialized knowledge and dedication. This finding suggests that the pre-services teachers had very high expectations with respect to their career decision-making (Lee et al., 2019; Fokkens-Bruinsma \& Canrinus, 2012; Richardson \& Watt, 2006).

Another interesting finding was subject-specific interest which was not highly rated as a motivational factor. This result contradicts previous findings (for example Stellmacher et al., 2020) that subject-specific and educational interest are significant motivational factors and were relevant in terms of pre-service teachers' career choice motivation.

\subsection{Pre-Service Teachers' Motivation to Teach Electricity as a Practical Subject Based on Gender}

Findings from the study (independent $t$-test results) showed that men and females differed significantly across seven of the motivational constructs for choosing to teach electricity as a practical subject in their future careers. The study also demonstrates that there were no significant differences between male and female pre-service teachers for the construct previous teaching and learning experiences.

The gender differences were observed as expected. This result supports claims (for e.g., Lee et al., 2019; Serra et al., 2019) that gender does influence perceptions of occupations, and individuals belonging to both genders set personal goals based on their expected career pathways, for example perceptions of task return. However, it challenges studies that have found no significant differences between male and female pre-service teachers for choosing teaching as a career (Abonyi et al., 2020; Stellmacher et al., 2020).

Descriptive statistics show that female preservice teachers rated self-efficacy beliefs, time for family, job security and social utility values significantly higher than the male pre-service teachers. This result is consistent with other studies that found that pre-service female teachers demonstrate stronger motivations with regard to job security, time for family and making a social contribution as compared to their male counterparts (Abonyi et al., 2020; Barni et al., 2019; Nesje et al., 2018; Watt et al., 2013). The lowest mean rating for choosing teaching among the pre-service teachers was fallback career (Male $\mathrm{M}=3.91$; Female $\mathrm{M}=2.44$ ). This finding is interesting as only males chose teaching as a fallback career. Considering that most participants were women, and they did not choose teaching as a fallback career, this finding is congruent with results of previous studies that fallback career is a low rated motivational factor (Abotsi et al., 2020; Glutsch \& König, 2019; Nesje et al., 2018; Bilim, 2014). These findings also challenge the claims of Dietrich and Lazarides (2019) that females do not have a high motivation profile as males.

\subsection{Pre-Service Teachers' Motivation to Teach Electricity as a Practical Subject Based on Year of Study}

Results of the one-way ANOVA and post-hoc test show that were significant differences $(\mathrm{p}=>.05)$ between 1 st, 2nd, and 3rd year pre-service teachers with regard to their perceptions associated social utility values and fallback career. Previous research has found that social utility value is a common and strong motivator for pre-service teachers and that there were significant differences by career point and academic teaching level (Ponnock et al., 2018). There were no significant differences between the groups for subject-specific interest, self-efficacy beliefs, job security, time for the family, previous teaching and learning experiences and task demand/return.

It is important to note that the mean values for all the constructs except fallback career are relatively high for all groups (between $\mathrm{M}=4.40$ and $\mathrm{M}=3.11$ ). However, the group mean differences reveal that the ratings of the pre-service teachers who are in their third year were not significantly higher than the pre-service teachers in the 
$1^{\text {st }}$ and $2^{\text {nd }}$ years. This result is not consistent with studies confirming that that older students are more likely to have higher scores for motivational factors than their younger counterparts, for example intrinsic career value, self-efficacy beliefs, job security, time for the family and social utility values (Ponnock et al., 2018; Wyatt-Smith et al., 2017). Overall, the difference across groups indicates that as pre-service teachers proceed along their education, their motivational profiles do not remain relatively stable.

\section{Conclusion}

This study has illuminated some prominent findings regarding pre-service teachers' motivation for the choice of electricity as a practical subject. Males and females differed significantly across seven of the eight motivational constructs examined in this study. Female pre-service teachers appeared to be more motivated to choose teaching electricity as a practical subject than males. Unusually, females were more extrinsically motivated than males. This suggests that females considered the extrinsic factors such as time for family, job security, etc. as important when making their career choices. The pre-service teachers' year of the study showed significant variations only with regard to social utility values and fallback career. In general, the results showed that self-efficacy beliefs, social utility value, time for family, job security, and prior experience of teaching and learning are important determinants to the decision of becoming pre-service teachers. Fall back career was the least important motivational factor that influenced the pre-service teachers for choosing teaching as a career. The findings support the applicability of the expectancy-value theory and the FIT-Choice model and provide new insights into career choices of pre-service teachers.

This is one of the very few studies to measure the importance of pre-service motivational factors in the Kuwaiti context. It adds to existing literature as most of the existing work regarding pre-service teachers' career choice motivations has focused on characterizing more broadly why teachers become teachers. Thus, this investigation represents a step forward in defining how gender and year of study might impact their experiences. Moreover, the results add additional evidence of the predictive validity of the FIT-Choice scale and its applicability to the Kuwaiti context.

An important theoretical implication of the current study is that pre-service teachers are undeniably a distinct category of students with a differential pattern of career choice motivation. Practical implications stem from the results related to the different motivations of the pre-service teachers. One implication is that the knowledge on their career choice motivations, especially the range of values and factors that impact pre-service teachers' decisions, could be applied when recruiting teachers to schools and higher education.

This study, which provides valuable insights into career choice motivation of pre-service teachers, also acknowledges some limitations. First, the sample was comparatively small as the researcher was unable to access students due to social distancing and other pandemic related restrictions. Another limitation was related to the reliance on self-report data and the short time span of the study. A mixed methods research design which uses a qualitative phase could help in providing a holistic and person-oriented perspective and in understanding how gender differences in motivation evolve in different groups of students.

\section{References}

Abonyi, U. K., Awhireng, D., \& Luguterah, A. W. (2021). Motivations of pre-service teachers in the colleges of education in Ghana for choosing teaching as a career, Cogent Education, 8(1), 1870803, https://doi.org/10.1080/2331186X.2020.1870803

Abotsi, A. K., Dsane, C. F., Babah, P. A., \& Kwarteng, P. (2020). Factors influencing the choice of teaching as a career: An empirical study of students in colleges of education in Ghana. Contemporary Social Science, 15(4), 446-460. https://doi.org/10.1080/21582041.2019.1675092

Ahrens, R. D., Lirani, L. D., \& de Francisco, A. C. (2020). Construct Validity and Reliability of the Work Environment Assessment Instrument WE-10 International Journal of Environmental Research and Public Health, 17, 7364. https://doi.org/10.3390/ijerph17207364

Alenezi, E. G. (2018). An Investigation of Teachers' Beliefs and Attitudes Regarding the Use of Tablet Computers as a Pedagogical Tool in Teaching Practical Studies (Electricity and Electronics) in Kuwaiti Intermediate Schools (Doctoral thesis, University of Southampton). Retrieved from https://eprints.soton.ac.uk/424740/

Bandura, A. (1997). Self-efficacy: the exercise of control. New York: Freeman.

Barni, D., Danioni, F., \& Benevene, P. (2019). Teachers' Self-Efficacy: The Role of Personal Values and Motivations for Teaching. Frontiers in psychology, 10, 1645. https://doi.org/10.3389/fpsyg.2019.01645 
Bergmark, U., Lundström, S., Manderstedt, L., \& Palo, A. (2018). Why become a teacher? Student teachers' perceptions of the teaching profession and motives for career choice. European Journal of Teacher Education, 41(3), 266-281, https://doi.org/10.1080/02619768.2018.1448784

Bianco, C. (2017). Education, a mirror of women advancement- The Case of Kuwait. Retrieved from https://www.egic.info/education-in-kuwait

Bilim, I. (2014) Pre-service elementary teachers' motivations to become a teacher and its relationship with teaching self-efficacy, Procedia-Social and Behavioral Sciences, 152, 653-661 https://doi.org/10.1016/j.sbspro.2014.09.258

Bourn, D. (2016). Teachers as agents of social change. International Journal of Development Education and Global Learning, 7(3), 63-77. https://doi.org/10.18546/IJDEGL.07.3.05

Brandmo, C., \& Nesje, K. (2017). Factors motivating students to become secondary school teachers: Evidence from Norway. In H. G. Watt, P. W. Richardson, \& K. Smith (Eds.), Global Perspectives on Teacher Motivation (pp. 95-125). New York: Cambridge University Press. https://doi.org/10.1017/9781316225202.004

Chesnut, S. R., \& Burley, H. (2015). Self-efficacy as a predictor of commitment to the teaching profession: A meta-analysis. Educational Research Review, 15, 1-16. https://doi.org/10.1016/j.edurev.2015.02.001

Den Brok, P., van der Want, A., Claessens, L., Pennings, H., Brekelmans, M., \& van Tartwijk, J. (2013). Teachers' choices for the teaching career and their teacher-student interpersonal relationships in the classroom: Investigating the Dutch context. Annual meeting of the American Educational Research Association, San Francisco, April 26-May 1, 2013.

Dietrich, J., \& Lazarides, R. (2019). Gendered Development of Motivational Belief Patterns in Mathematics Across a School Year and Career Plans in Math-Related Fields. Frontiers in Psychology, 10, 1472. https://doi.org/10.3389/fpsyg.2019.01472

Floden, R., Stephens, A., \& Schere, L. (2020). Changing Expectations for the K-12 Teacher Workforce Policies, Preservice Education, Professional Development, and the Workplace. The National Academies Press, Washington, DC. https://doi.org/10.17226/25603

Fokkens-Bruinsma, M., \& Canrinus, E. T. (2012) The Factors Influencing Teaching (FIT)-Choice scale in a Dutch teacher education program. Asia-Pacific Journal of Teacher Education, 40(3), 249-269. https://doi.org/10.1080/1359866X.2012.700043

Fray, L., \& Gore, J. (2018). Why people choose teaching: A scoping review of empirical studies, 2007-2016. Teaching and Teacher Education, 75. https://doi.org/10.1016/j.tate.2018.06.009

Garra-Alloush, I., Chaleila, W., \& Watted, A. (2021) Close to the Heart or Close to the Home? Motivational Factors Influencing EFL Teaching as a Career Choice among Female Arab Citizens of Israel Students. English Language Teaching, 14(1), 48-57. https://doi.org/10.5539/elt.v14n1p48

Glutsch, N., \& König, J. (2019). Pre-service teachers' motivations for choosing teaching as a career: Does subject interest matter? Journal of Education for Teaching, 45(5), 494-510 https://doi.org/10.1080/02607476.2019.1674560

Gulf News. (Dec, 2020). Kuwait halts hiring of teachers from abroad. Retrieved from https://gulfnews.com/world/gulf/kuwait/kuwait-halts-hiring-of-teachers-from-abroad-1.76059319

Halek, M., Holle, D., \& Bartholomeyczik, S. (2017). Development and evaluation of the content validity, practicability and feasibility of the Innovative dementia-oriented Assessment system for challenging behaviour in residents with dementia. BMC Health Services Research, 17, 554. https://doi.org/10.1186/s12913-017-2469-8

Han, J., \& Yin, H. (2016) Teacher motivation: Definition, research development and implications for teachers, Cogent Education, 3(1), 1217819, https://doi.org/10.1080/2331186X.2016.1217819

Han, S. W., Borgonovi, F., \& Guerriero, S. (2018). What motivates high school students to want to be teachers? The role of salary, working conditions, and societal evaluations about occupations in a comparative $\begin{array}{lllll}\text { perspective. American Education Research Journal, 39. } & \text { 55(1), }\end{array}$ https://doi.org/10.3102/0002831217729875

Harackiewicz, J. M., Smith, J. L., \& Priniski, S. J. (2016). Interest Matters: The Importance of Promoting Interest in Education. Policy insights from the behavioral and brain sciences, 3(2), 220-227. 
https://doi.org/10.1177/2372732216655542

Heinz, M. (2015). Why choose teaching? An international review of empirical studies exploring student teachers' career motivations and levels of commitment to teaching. Educational Research and Evaluation, 21(3), 258-297, https://doi.org/10.1080/13803611.2015.1018278

Higgins, S., Maber, E., Cardozo, M. L., \& Shah. R. (2016). The Role of Education in Peacebuilding Country Report: Myanmar. Netherlands: University of Amsterdam.

Howard-Jones, P., \& Jay, T. (2016). Reward, learning and games. Current Opinion in Behavioral Sciences, 10, 65-72. https://doi.org/10.1016/j.cobeha.2016.04.015

Htang, L. K. (2019). Motivations for choosing teaching as a career: teacher trainees' perspective from a Myanmar context. Journal of Education for Teaching. https://doi.org/10.1080/02607476.2019.1674561

Kim, H. (2015). Early Childhood Pre-service Teachers' Beliefs about e-Portfolios and Experiences in the Development of an e-Portfolio in the United States. International Journal of Early Childhood Education, 21(1), 39-56. Retrieved from http://210.101.116.28/W_files/kiss5/29204208_pv.pdf

Kyriacou, C., \& Coulthard, M. (2000). Undergraduates' Views of Teaching as a Career Choice. Journal of Education for Teaching, 26(2), 117-126. https://doi.org/10.1080/02607470050127036

Lauermann, F., Karabenick, S. A., Carpenter, R., \& Kuusinen, C. (2017). Teacher motivation and professional commitment in the United States: The role of motivations for teaching, teacher self-efficacy and sense of professional responsibility. In H. M. G. Watt, P. W. Richardson, \& K. Smith (Eds.), Global Perspectives on Teacher Motivation (pp. 322-348). New York: Cambridge University Press. https://doi.org/10.1080/02607470050127036

Lee, J. A., Kang, M. O. \& Park, B. J. (2019). Factors influencing choosing teaching as a career: South Korean pre-service teachers. Asia Pacific Educational Review, 20, 467-488. https://doi.org/10.1007/s12564-019-09579-z

Low, E., Ng, P., Hui, C., \& Cai, L. (2017). Teaching as a Career Choice: Triggers and Drivers. Australian Journal of Teacher Education, 42(2). https://doi.org/10.1080/02607470050127036

Maloney, P. (2013). Professional Socialization of Teachers. In J. Ainsworth (Ed.), Sociology of Education: An A-to-Z Guide. Thousand Oaks, CA: Sage Publication.

Mariscal, D. C., \& Delgado, F. J. H. (2016). Main Motivations of Students of Childhood Education and Primary Education to Become Teachers. Mediterranean Journal of Social Sciences, 7(6), 153. https://doi.org/10.5901/mjss.2016.v7n6p153

Martin, L., \& Mulvihill, T. (2016). Voices in education: Teacher shortage: Myth or reality? Teacher Educator, 51, 175-184. https://doi.org/10.1080/08878730.2016.1177427

Marušić, I., Jugović, I., \& Ivanec, T. P. (2017). How personality dimensions and motivation to teach shape the learning achievement goals of Croatian future teachers. In H. G. Watt, P. W. Richardson, \& K. Smith (Eds.), Global Perspectives on Teacher Motivation (pp. 220-242). New York: Cambridge University Press. https://doi.org/10.1017/9781316225202.008

Matusovich, H. M., Carrico, C., Paretti, M. C., \& Boynton, M. (2017). Engineering as a career choice in rural Appalachia: Sparking and sustaining interest. International Journal of Engineering Education, 33, 1-13.

McLean, L., Taylor, M., \& Jimenez, M. (2019). Career choice motivations in teacher training as predictors of burnout and career optimism in the first year of teaching. Teaching and Teacher Education, 85, 204-214 https://doi.org/10.1016/j.tate.2019.06.020

Moreau, M. P. (2014). Becoming a secondary school teacher in England and France: Contextualising career 'choice'. Compare: A Journal of Comparative and International Education. https://doi.org/10.1080/03057925.2013.876310

Moss, J. D. (2020). "I was told to find what broke my heart and fix it:" College students explain why they want to become teachers. Cogent Education, 7(1). https://doi.org/10.1080/2331186X.2020.1734284

Murayama, K., \& Kitagami, S. (2014). Consolidation power of extrinsic rewards: Reward cues enhance long-term memory for irrelevant past events. Journal of Experimental Psychology: General, 143, 15-20. https://doi.org/10.1037/a0031992

Murayama, K., Kitagami, S., Tanaka, A., \& Raw, J. A. (2016). People's naiveté about how extrinsic rewards 
influence intrinsic motivation. Motivation Science, 2, 138-142. https://doi.org/10.1037/mot0000040

Nesje, K., Brandmo, C., \& Berger, J. (2018) Motivation to Become a Teacher: a Norwegian Validation of the Factors Influencing Teaching Choice Scale. Scandinavian Journal of Educational Research, 62(6), 813-831, https://doi.org/10.1080/00313831.2017.1306804

$\mathrm{Ng}$, P. T. (2015). What is quality education? How can it be achieved? The perspectives of school middle leaders in Singapore. Educational Assessment, Evaluation and Accountability, 27, 307-322. https://doi.org/10.1007/s11092-015-9223-8

Nie, Y., Tan, G. H., Liau, A. K., Lau, S., \& Chua, B. L. (2013). The roles of teacher efficacy in instructional innovation: Its predictive relations to constructivist and didactic instruction. Educational Research for Policy and Practice, 12(1), 67-77. https://doi.org/10.1007/s10671-012-9128-y

Odom, L. R., \& Morrow, J. R. (2006) What's this r? A Correlational Approach to Explaining Validity, Reliability and Objectivity Coefficients. Measurement in Physical Education and Exercise Science, 10(2), 137-145. https://doi.org/10.1207/s15327841mpee1002_5

OECD. (2019). PISA 2018 results. Retrieved from https://www.oecd.org/pisa/PISA-results_ENGLISH.png

Oxford Business Group. (2017). Government reforms to change Kuwait's education sector. The Report: Kuwait 2017. Retrieved from https://oxfordbusinessgroup.com/overview/time-transition-extensive-governmentreforms-signal-change-kuwait $\% \mathrm{E} 2 \% 80 \% 99$ s-education-sector

Ponnock, A., Torsney, B. M., \& Lombardi, D. (2018). Motivational Differences Throughout Teachers' Preparation and Career, New Waves Educational Research \& Development, 21(2), 26-45.

Qin, T. Y., Zarina, R., Zainuddin, I., Jasmine, S., Shing, N. K., Sunitha, M., \& Abdelaziz, N. (2015). Teachers' background factors and its relation to motivation. Malaysian Online Journal of Educational Management, $3(2), 1-17$.

Sadeghi, A. S. H., Yazdani, S., \& Afshar, L. (2019). Professional socialization: an analytical definition. Journal of Medical Ethics and History of Medicine, 12, 17. https://doi.org/10.18502/jmehm.v12i17.2016

Salisu, W. J., Nayeri, N. D., Yakubu, I., \& Ebrahimpour, I. (2019). Challenges and facilitators of professional socialization: A systematic review. Nursing Open, 6(4), 1289-1298. https://doi.org/10.1002/nop2.341

Schonert-Reichl, K. (2017). Social and Emotional Learning and Teachers. The Future of Children, 27(1), 137-155. https://doi.org/10.1353/foc.2017.0007

Serra, P., Soler, S., Camacho-Miñano, M. J., Rey-Cao, A., \& Vilanova, A. (2019) Gendered Career Choices: Paths Toward Studying a Degree in Physical Activity and Sport Science. Front. Psychol., 10, 1986. https://doi.org/10.3389/fpsyg.2019.01986

Shin, S., Lee, J.-K., and Ha, M. (2017). Influence of Career Motivation on Science Learning in Korean High-School Students. Eurasia Journal of Mathematics, Science and Technology Education, 13(5), 1517-1538. https://doi.org/10.12973/eurasia.2017.00683a

Stellmacher, A., Ohlemann, S., Pfetsch, J., \& Ittel, A. (2020). Pre-service teacher motivation: A comparison of vocational education and training and comprehensive schoolteachers, International Journal for Research in Vocational Education and Training, 7(2), 214-236. https://doi.org/10.13152/IJRVET.7.2.5

Suryani, A. (2017). Motivations and Aspirations of Teacher Education Students in Indonesia. In H. Watt, P. Richardson, \& K. Smith (Eds.), Global Perspectives on Teacher Motivation (Current Perspectives in Social and Behavioral Sciences, pp. 248-296). Cambridge: Cambridge University Press.

Tomšik, R. (2016). Choosing Teaching as a Career: Importance of the Type of Motivation in Career Choices. TEM Journal, 5(3), 396-400.

Topkaya, E. Z., \& Uztosun, M. S. (2012). Choosing Teaching as a Career: Motivations of Pre-service English Teachers in Turkey Journal of Language Teaching and Research, 3(1), 126-134. https://doi.org/10.4304/jltr.3.1.126-134

Torsney, B. M., Lombardi, D., \& Ponnock, A. (2019). The role of values in preservice teachers' intent ions for $\begin{array}{lllll}\text { professional engagement. } & \text { Educational } & \text { Psychology, } & 39(1), & \text { 19-37. }\end{array}$ https://doi.org/10.1080/01443410.2018.1504892

Watt, H. M. G., \& Richardson, P. (2012). An introduction to teaching motivations in different countries: Comparisons using the FIT-Choice scale. Asia-Pacific Journal of Teacher Education, 40(3), 185-197. 
https://doi.org/10.1080/1359866X.2012.700049

Watt, H. M. G., \& Richardson, P. (2007). Motivational factors influencing teaching as a career choice: Development and validation of the FIT-Choice scale. The Journal of Experimental Education, 75, 167-202. https://doi.org/10.3200/JEXE.75.3.167-202

Watt, H. M. G., Richardson, P. W., \& Smith, K. (Eds.) (2017). Global Perspectives on Teacher Motivation (1st ed.). Cambridge University Press. https://doi.org/10.1017/9781316225202

Watt, H. M. G., Richardson, P. W., Klusmann, U., Kunter, M., Beyer, B., Trautwein, U., \& Baumert, J. (2012) Motivations for choosing teaching as a career: An international comparison using the FIT-Choice scale. Teaching and Teacher Education, 28(6), 791-805. https://doi.org/10.1016/j.tate.2012.03.003

Watt, H. M., Richardson, P. W., \& Wilkins, K. (2014). Profiles of professional engagement and career development aspirations among USA pre-service teachers. International Journal of Educational Research, 65, 23-40. https://doi.org/10.1016/j.ijer.2013.09.008

Wigfield, A., \& Eccles, J. S. (2000). Expectancy-value theory of achievement motivation. Contemporary Educational Psychology, 25, 68-81. https://doi.org/10.1006/ceps.1999.1015

Wyatt-Smith, C., Du Plessis, A., Wang, J., Hand, K., Alexander, C., \& Colbert, P. (2017). Why choose teaching? A matter of choice: Evidence from the field. Brisbane, Queensland: Learning Sciences Institute Australia. Retrieved from https://cdn.qct.edu.au/pdf/WhyChooseTeachingReport.pdf

\section{Copyrights}

Copyright for this article is retained by the author(s), with first publication rights granted to the journal.

This is an open-access article distributed under the terms and conditions of the Creative Commons Attribution license (http://creativecommons.org/licenses/by/4.0/). 